\title{
Aesthetic Resistance Theory: The Use of Mythology in Selected Poems by Nancy Morejón
}

\author{
English Department, Faculty of Arts, Helwan University \\ Marwa Saad \\ marwasaad2007@yahoo.com
}

\begin{abstract}
The present paper first sheds light on resistance theory, aesthetic theory, and aesthetic resistance theory as an attempt to form the term "aesthetic resistance in poetry." Then, in light of this term, the researcher examines selected poems of Nancy Morejón on the ground of using mythology as an aesthetic resistance instrument to resist oppression against Africans minority. Resistance discourse is any act intended to resist oppression whether a slave master, multinational cooperation, occupying or ruling power, and causes transformation in the existing order to give space for the marginalized groups. Resistance poetry is the poet's innovations either linguistically or any other innovations which brings ethical and political transformations in the oppressive structure.

Resistance literature creates new world that leads to new perspectives and establishes examples that bring ethical and political transformations to oppressive structures. Gail Weiss believes that resistance literature creates space for the marginalized to resist oppression through language to form ethical and political transformation (Weiss 97). Accordingly, the resistance writers across cultures believe that their non-violent struggle and literary historical reclamation are important area of cultural territory. For instance, the poet Nancy Morejón resists oppression and marginalization through her poetry. Aesthetic theory reveals the true content of the work of art and describes art from within. Aesthetic dwells in the work of art that forms opinion and changes the society.

Nancy Morejón is a postmodern resistance women poet who represents the voice of the Afro-Cuban experience as they suffer from marginalization. The poet regards her poems as primal instrument of resistance that can act as effective socio-political actor. Morejón does not have any expression of selfpity that might evoke or reinforce the notion of passivity. The poet calls on African slaves for transculturation, to integrate into Caribbean culture and consider it as their new homeland through mythology.
\end{abstract}


Key Words: Nancy Morejón, resistance, resistance culture, resistance literature, aesthetic resistance, Orisha, Yoruba, Myth.

The paper is an attempt to investigate aesthetic resistance poetry in terms of resistance discourse, aesthetic theory, and resistance literature. Then, the term aesthetic resistance in poetry will be outlined to the reader and applied to analyze selected poems of Morejón in relation to mythology. The researcher selected eight poems: "The Eyes of Elegguá", "Rebirth", "Mother", "Coffee", "Home", "Worlds", "By the Gulf" and "In Praise of Nieves Fresneda" as they are rich poems of African mythology. The poems reveal the relationship between mythology and resistance of identity oppression. The paper seeks to answer these questions; What is aesthetic resistance in poetry? Does Morejón's resistance poetry create counter discourse in the history of Cuba and an identity for a whole nation? How does the poet redefine her black identity experience? And how far does employing mythology as an instrument of aesthetic resistance places Morejón poems' as an example of aesthetic resistance poetry in relation to identity oppression?

Nancy Morejón was born in 1944 in Cuba. She is one of the most distinguished modern Cuban female poets. Moréjon was a celebrated AfroCuban poet, feminist, revolutionary poet, essayist, critic, editor, journalist, and translator. Morejón was the first African Cuban student to receive a degree in the Faculty of Arts at Havana University, where she majored in French. Morejón was the first black poet in Cuban history to be given the opportunity to publish widely and to acquire a professional status as a writer, critic, and translator. Moréjon was the winner of Cuba's National Literary Prize in 2001. The poet was also the first Cuban women to celebrate blackness in poetry following the footsteps of Nicolás Guillén ${ }^{i}$ (Lofton).

Morejón wrote twelve collections of poems, three monographs, a play, and four volumes of critical studies on Cuban and Caribbean history and literature as well as numerous poems and articles that were published in anthologies, literary journals and mass media. Some of her poems transcended literary genre and were dramatized in mime recitals by Morejón herself. Moréjon created poetry of

social decolonizing consciousness while at the same time revealing a profound consciousness of her poetry. In every instance, Morejón unveils the essence of her human social cultural and ideological world always filtered through her aesthetic lens. (Cook 70) 
The poet created poetry that was at the service of society, a subjective poetry with precise images and details of the concrete world around the poet. It deals with the poet personal believes and feelings.

\section{Aesthetic Resistance Theory}

Critics from diverse backgrounds address themselves to resistance discourse. Michael Hardt believes that resistance discourse brings new perceptions that can change the dominant power. Gail Weiss and Julia Kristeva believe in the power of the work of art that can change marginalized beliefs to resist the dominant power.

According to Michael Hardt and Gail Weiss, resistance discourse creates a new world that leads to new perspectives and establishes examples that bring ethical and political transformations to oppressive structures. "The study of resistance discourse helps in understanding the subjectivities capable of creating a new world or leading to a new vision of freedom", (Hardt 65). While Weiss says, when an artist makes "linguistic and other innovations in fictional work, he/she establishes patterns that can bring ethical and political transformations within the oppressive structures" (Weiss 97). The marginalized believe in the power of the work of art as their resistance literature creates changes in their repressive societies.

Julia Kristeva agrees with Gail Weiss on the significance of language in resistance as Weiss believes that the marginalized can resist oppression through language to achieve ethical and political transformation. Kristeva maintains that women "can get beyond patriarchal language and patriarchal thinking by seeking access to what she calls the semiotic dimension of language" (Kristeva 134). Kristeva argues that the language has two dimensions; symbolic and semiotic. In symbolism the words operate, and meanings are endorsed by them. In contrast, the semiotic dimension of language consists of elements as intonation (sound, tone of voice, volume), rhythm, and body language, that occur as we speak and reveal our feelings. Thus, semiotic is the way we speak that reveals the emotions that come across in our voice and body language as we talk (Kristeva 134).

Selwyn R. Cudjoe ${ }^{\mathrm{ii}}$ and Lesley Brown define resistance as any act intended to resist oppression whether a slave master, multinational cooperation, occupying or ruling power. David Couzens Hoy, Professor of Philosophy, believes that resistance causes transformation in the existing order while the critic Usha Bande argues that resistance can take away this power and give 
space for the marginalized groups. Adrian Grafe and Jessica Stephens have another perspective of resistance that can fight even savagery to improve the lives of the people to be their own.

Cudjoe, the renowned critic on Caribbean literature and Professor of African studies, defines resistance as "any act or complex of acts designed to rid people of their oppressors, be their slave masters or multinational corporations" (Cudjoe 19). Brown argues, resistance "is the act or action of resisting, opposing or withstanding; organized covert opposition to an occupying or ruling power" (Brown 2562). When power turns into domination, it restricts the constructive possibilities of the socio-political order, which may lead to the emergence of resistance. Hoy says, "Resistance can challenge and even destabilize the existing order to force some transformations in it" (Hoy 66). Hoy argues, the emergence of such resistance may not disrupt power, but it allows space for individuals to enhance the possibilities of resistance against unjust and oppressive order (Hoy 92-93).

Bande, defines resistance as "the strategy that has the potential to remove the dominant power if not dismantle it" (Bande 1). She states that resistance may involve duplication of the hegemonic prejudice that regulates the identities of the subaltern groups and silence the other groups. "Resistance recognizes the need to hear the voices of the dispossessed and aims to bring the marginalized into the centre. Therefore, domination and resistance are interlinked, and power is central to both" (Bande 2). Resistance, as Bande writes, engages with oppressive power structures, and questions the responsible of the injustices under those structures. Consequently, resistance reshapes the spaces available to the marginalized, and helps to transform the existing order (Bande 1-4). Grafe and Stephens argue that, resistance is one of the methods to improve our life and asserts the man ethics (Grafe 1).

John Foran notes that resistance movements do not seek a radical recasting of national societies through seizure of power but seek social justice through peaceful means. These resistance movements create spaces for free discussion of political, economic, and culture alternatives to the weak or marginalized (Foran 12). Hardt agrees as well, with Foran that the resistance of the weak confronts the strategies of the dominant order and upsets the established hierarchies to restructure the unequal order. Resistance brings out the potential superiority of the weak, as it transforms weakness into strength, as Hardt believes. In other words, resistance of the marginalized converts passive 
subjects into active ones. Resistance awards oppressed the power to change life of submission (Hardt 53-54).

Accordingly, there are two types of resistance: violent resistance and nonviolent resistance. Violent Resistance "is any action, intentionally taken to harm the life, health, or welfare of another human being for the purpose of resisting oppression" (Bowser 8). On the other hand, nonviolent resistance includes public and collective resistance, everyday resistance, cultural resistance, and resistance literature. According to Michel de Certeau; nonviolent resistance is basic in the everyday practices through which the 'user' or consumer' in the everyday practices of reading, writing and speaking can manifest resistance. The products (stories, legends, discourses, newspapers articles, television) of the dominant order are consumed variedly by the user (consumer) through everyday practices to bring innumerable transformations in the imposed order. The transformations that occur within the dominant cultural adapt the imposed order to the interests of the users /consumers. Therefore, the everyday resistance can modify the common perceptions and help to reconfigure the common order (Certeau 28-29).

Hsiao and Lim state that public and collective resistance, such as rebellions, demonstrations and revolutions cause several transformations in the oppressive structures through everyday practices and modes of subjectification of the marginalized. Every uprising of non-violent resistance and civil disobedience demonstrate the inherent power of the weak and attempt to suggest the following: "The domineer has only two eyes, only two hands, only one body, no more than the power that you confer upon him to destroy you. . . . How would he dare to assail you if you did not allow him to? (Hsiao 19)." Hsiao and Lim, document nonviolent resistance and give examples of oppressed people against those in power across ages and continents. For instance, the claims for equality and justice made by Mohandas K. Gandhi, Edward Said, and many others seek empowerment of the underprivileged.

The resistance culture of the Caribbean played pivotal roles in the emancipation of enslaved Africans. One of the primary motivating forces behind resistance culture among African-Caribbean's was the search for an African identity. Anisa Seudatsingh discussed in her article "Responses of the Caribbean People to Oppression and Genocide" at the website SlideShares that Africans in the Caribbean used their sticks to provide rhythmic sound, although to slave-owners this was unsettling, as sticks were effective weapons. This was soon banned, and the Africans had to find other forms of rhythm. They used to 
hammer the surfaces of drums and dividing them to produce different sounds, the steel band was born. The steel drum made a powerful political statement as it symbolized African creativity, identity, power, and ownership (Seudatsingh).

As for aesthetic of art, the concept of art is a controversial point between different aesthetic critics such as Immanuel Kant and Adorno Theodor. Whereas Kant believes that aesthetic is in the beauty of pure art, Theodor believes that aesthetic dwells in the work of art that forms the opinion and changes of the society. Theodor defines aesthetic in his book Aesthetic Theory as a "means to breach this externality of aesthetics of art" (Theodor xii). Aesthetic theory reveals the true content of the work of art and describes art from within. It discloses the emphatic role and the exceptional position of the artwork and its relation to society, culture, and history (Theodor xii).

The paper agrees with Theodor perspectives. The work of art should have innovation, negation and raises question. The aesthetic of the work of art relies in its development of artistic processes which resembles social development. Though, aesthetic is the purest expression of the human desire to resist and create new perspectives of life, the work of art is the means of resisting oppression and forming opinion. Art is used for the purpose of "forming opinion" as it is a social reflection (Theodor 230).

Cudjoe as well asserts Theodor's aesthetic perception of literature as used for forming opinion and as a social reflection. Cudjoe advocates that the aesthetic of the work of art is associated with the content and the virtue of its power to change reality. The researcher argues that, since Theodor and Cudjoe define the aesthetic of the work of art by its function to society, forming opinion, and its relation to real life, then, resistance literature discusses the repressive ideologies and demonstrates the power of the powerless.

Poetry is one of the effective forms of resistance and its role in the liberation struggle is a crucial one. One of the influential tools of resistance in poetry is the collective memory. The poet implements various forms of collective memory to resist oppression. For instance, he/she writes about everyday life objects, the most sacred symbols or the memory of important historical events in his/her country. The novelist, playwright, critic, and prominent public intellectual Elias Khouri in his article "The world of meanings in Palestinian poetry", argues that, "language is the very framework of steadfastness (sumūd)...language is the source of the collective memory" (Khouri 245). It is the basic national value which must be preserved. Khouri says, "The role of poetry is a major one, not only because it is more powerful 
than other forms of writing as a means of political organization, but also because it sustains within the popular memory and the national continuity" (Khouri 245). Therefore, most of the revolutionary leaders in South Africa are poets. Cudjoe gives example of Angola's greatest poet António Agostinho Neto who led the fight for independence and became the first president of Angola. When resistance is the chief preoccupation of a country, the aesthetic must become political. Since these men fight to the death, poetry and literature become the conscious unity of will, thought, and desire merged with revolutionary activity (Cudjoe 58-59). Morejón resists marginalization through her poems.

In corroborating the above, aesthetic resistance in general calls into question the established order. Therefore, aesthetic resistance in poetry includes an organic unity of vision and technique rather than mere focus on ideology or rhetoric. This area is significantly under developing particularly in its application to Caribbean poetry. The present paper applies the term "aesthetic resistance in poetry" on Morejón's selected poems. Mythology is one of the poet aesthetic resistance instruments that the poet implemented to resist oppression and marginalization as she believes in integration and non-violent resistance. Definition of myth will be tackled first before analysing how Morejón resists by mythology.

Transculturation for Morejón involves a dynamic integration at every level; food, dress, music, folklore, religious belief, and community interaction. West sums up the idea of transculturation as follows;

Transculturation signifies constant interaction, transmutation between two or more cultural components whose unconscious end is the creation of a third cultural whole, that is, culture-new independent, although its bases, its roots, rest on preceding elements... No element is superimposed on the contrary, each one becomes a third entity. One remains immutable. All change and grow in a give and take approach which engenders a new texture (West 212).

Morejón in her interview with Sapphire, agrees with West "whoever wants to understand Cuba cannot ignore its mestizo condition in which the Hispanic and African components cannot be divided because they have created a cosmovision that is authentically original" (Lofton). The poems are a symbol of cultural resistance outlined by expressions of progress and independence (Lofton).

\section{Mythology in Literature}


Myth is a story which is believed to be true and has its origin in the history and culture of people. Robert J. Lenardon and Mark P. O. Morford in Classical Mythology states that "The word myth comes from the Greek word mythos which means word, speech, tale, or story, and that is essentially what a myth is: a story. Some would limit this broad definition by insisting that the story must have proven itself worthy of becoming traditional." Myth either is in a written form or in different art forms as painting, sculpture, music, dance, mime, dram, song, opera, or movies (Lenardon 1).

Africans associates' myth with stories about Gods or Orishas ${ }^{\mathrm{iii}}$ explaining and answering questions raised by the human being. Jones Jaja in his article Myths in African Concepts of reality states that myths are one of the main accounts of African societies. Philosophers and historians often used it to comprehend the African history and culture (Jaja 9). Apostel argues that myths use images, philosophy, concepts, and is always associated with mystery and illogic. Mythological society is unsystematic and deals with the sacred (Apostel $15)$.

Accordingly, myth is not an intellectual explanation or an artistic imagery but "living chronicles in the minds of Africans" as Jaja argues (Jaja 9). Myths contain and express the history, the culture and the inner experience of the African himself. Africans use myths to explain how things came to be through the efforts of a supernatural being. It is concrete and expresses life better than what abstract thought can do (Jaja 9).

Most of West African's religion is Yoruba ${ }^{\text {iv }}$ which is based on myths. Jim Landry states that, the Yorubas are deeply religious people and have a strong belief in the existence of supernatural powers. These supernatural powers affect the everyday life of man for good or evil. There are two types of Yoruba good and evil. The good supernatural powers are two types: Gods or Orisha and the ancestors or Oku Orun. The Yoruba people whose forefathers were sold into slavery maintain certain aspects of their religion in the countries of South America, Cuba, Jamaica, the Caribbean, and the United States of America (Landry 5-7).

Morejón picks mythology to resist oppression but through transculturation. Jossianna Arroyo in his article "Transculturation, Syncretism, and Hybridity". defined transculturation as a term coined by the Cuban anthropologist Fernando Ortiz in 1940. This term was a revision of the term acculturation introduced to US and British anthropology and social sciences by the Brolisnaw J. Malinowski in the 1920s and 1930s. The term appeared first in 
the work of US anthropologist J. W. Powell (1834-1902). Both theories were based on migration and migratory studies, and an analysis of the cultures of immigrant populations into the United States and Cuba (Arroyo 133).

Alan West in his article "Nancy Morejón: Transculturation, Translation and the Poetics of the Caribbean" defined transculturation as a phenomenon in which a new created culture formed from the historical and cultural translation to approach poetics of historical understanding. Transculturation, often under historical circumstances of very cruel distress, is a practice of cultural creativity and an act of social resistance. Through transculturation, the Caribbean's, and more specifically Cuban's, have created collective, sometimes contradictory, identities, and new approaches of knowing (West 967).

West argues that, transculturation signifies constant interaction, transmutation between two or more cultural components, whose unconscious end is a creation of a third cultural whole. This third culture is new and independent, although its roots rest on preceding elements. The mutual influence is determining as no element is superimposed on the other. On the contrary, each one becomes a third entity, and none remains unchallengeable. West believes that all the elements change and grow in a give and take approach which produces a new texture. Therefore, transculturation occurs in a culture that is subjugated under colonialism and slavery. It is able to incorporate, transform, and subtlety subvert oppression. West described Nancy Morejón as the "human and poetic embodiment of the word transculturation" (West 967). Morejón's poems are good example of transculturation in which she integrates profoundly elements form both African and Cuban culture.

\section{Mythology in the Poetry of Nancy Morejón}

Morejón refers to transculturation in her poems through mythology. The poems "The Eyes of Elegguá", "Rebirth", "Mother", "Coffee", "Home", "Worlds", and "By the Gulf" are rich poems of African mythology. For instance, the poem "The Eyes of Elegguá" resists marginalization through mythology as it signifies the importance of culture resistance which leads and gives the power to resist oppression. Morejón believes in the power of Orishas and "The Eyes of Elegguâ" brings out potential superiority of the marginalized as it transforms weakness into strength.

The poet refused to accept a life of submission and carved dignified space for her people. Morejón resisted marginalization and implemented aspects of African mythology and integrated with Cuban culture to create balance between both cultures. The poet said in her interview with Ramona Lofton that whoever 
wants to understand Cuba cannot ignore its "mestizo" in which Cuban and African cultures are mixed to the extent that it cannot be divided. The mixture of the two cultures have created a "cosmovision" that is reliably original (Lofton).

Tonight

by the doors of the big old reddish house

once more I have seen the warrior's eyes (Cook 164).

At the beginning of the poem, the poet sees the eyes of Elegguá at nighttime dancing like all the Santeria Orishas. Patricia González writes in "Yoruba Vestiges in Nancy Morejón's Poetry" that the Orisha Elegguá, one of the major Orishas, brings the messages from earth to Olofi, who has the power to solve all conflicts (González 956). Alan West states, roads and crossroads in Cuba must begin with the Afro-Cuban Orisha Elegguá as the owner of all the roads. He protects the entry of homes and ways, prevents harms from entering home. Elegguá is the Orisha of destiny, crossroads, and strongly linked to the unexpected. Therefore, Orisha invoked before all others because he is the Messenger of all the Gods (West 193). This reflects the integration between the two cultures, African and Cuban, as aspects form the African culture is now part of the Cuban culture.

Elegguá

tongue

bloodred like the hearts of iron tools Rubs space with a copper knife

Who will let him

If not the stone

or the white coconut

who will recover the seashells of his eyes (Cook 164).

West states, one day Elegguá found a coconut in the road while giving off a blinding light from his three eyes. He picked it up and took it home to his parents. However, his eyes did not shine, in another version of the story the eyes kept shining behind the door. Three days later he died and soon disasters hit the kingdom. Finally, the kingdom residents found the coconut behind the door, but it was empty and crawling with bugs. They put it in its place, a sacred stone which is the origin of Elegguá (West 193-4). Morejón recalls the story of Elegguá's eyes because she hoped to enlist all his seeing capabilities. As he personifies justice, knowing the best for humankind and the perfect balance in 
nature (West 194). The poet calls for believes' assimilation; all Cubans believe in Elegguá's power as the Africans.

If the eyes of elegguá would come back

they would cross the raging river once again

where the gods went away where the fish once swam

who would remember then the songs of birds

the great elegguá has tied my hands

and loosens them and runs away (Cook 164).

West notes that the poet is confused, and asks; are the eyes of Elegguá the source that gives her faith and power to resist or is it the faith that makes her see Elegguá's eyes? West clears the confusion that, possibly a little of both because to see things along the dark road, there is nothing better than to have Elegguá's eyes lighting the way, as if you are being protected by the Orisha's head lights (West 194).

Caribbean region entered the twentieth century as a society in great poverty, stubbornly resisting enslavement, and striving towards freedom. Violence was not only used in a physical sense to subjugate the people of the Caribbean but was implicit in the social and economic arrangements of the islands. Cudjoe in Resistance and Caribbean Literature states that, by 1830 a high percentage of blacks were still African born. Although by 1834 the slavery abolition had declared, all major decisions were still made through the colonial office. The slave did not yet control their own affairs and were only a little better off than slaves. Cudjoe gives examples of the latifundium; a large landed estate or ranch in ancient Rome or more recently in Spain or Latin America. Latifundium was typically worked by slaves and uprooted the farmers from their lands to convert and oblige the society to be at the service and dependent on the colonizer power. Against this background, the Caribbean in the twentieth century witnessed sequence of strikes that turned into demonstrations (Cudjoe 15-47).

Cudjoe articulates that it is possible to read certain historical references, although indirect they are. For instance, the African religion was the leader of cultural resistance and assisted the slaves in their resistance for liberation. In the Caribbean culture, religion essentially fashioned the sensibilities of the people and became their way or method for most of their actions (Cudjoe 23). West notes that, in this poem Elegguá is a warrior and his colors are red and black, which are the colors of the July $26^{\text {th }}$ Movement led by Fidel Castro. Cuba since 1959 has been defined as guerrilla society that includes warrior values such as, 
courage, determination, skill, and strength (West 195). In addition, it advocates Morejón's integration perspective between the Cuban identity and African identity.

The aesthetic resistance of "The Eyes of Eleggua" signifies the mythology as an aesthetic resistance instrument because Morejón strongly believes and is proud of her ancestor cultural. Morejón integrates aspects of African culture and religion with the Cuban history. African Cubans resisted oppression with the help of African Gods. African Cubans are now, not only part of the Cuban history, but they are rewriting the Cuban history. The poet has a powerful spirit to change the reality and rediscover the world around her. Thus, Morejón resists marginalization and calls for a Cuban identity for all Africans in Cuba. The poem advocates Harlow and Cudjoe perspective about the essential role of literature as a field of cultural resistance and the logic of creation to enable the common people to restructure the oppressive order.

Another example of mythology as a resistance instrument is when Morejón cites orisha "Yemayá" in many poems, either directly or through many references to the sea, such as, "Rebirth", "Mother", "Coffee", "By the Gulf", and "In Praise of Nieves Fresneda". González states, "Yemayá" is a female orisha that symbolizes maternity and womanhood. She is often associated with the moon and her name is derived from the Yoruba title "Yeyemo eja", which means "the mother whose children are the fish" (González 957). She is also the universal mother who gives birth to all other orishas. She rules over the sea, likes the sea, shows great quietness but also mighty force (González 957).

In the poem "Rebirth", for example, Morejón manifests her personal identification with the Orisha Yemayá

Daughter of ocean waters,

asleep in that womb

I am reborn

Out of the gun-powder

Shown over the mountain

By a guerrilla rifle

So the world in its turn

Might be reborn, (Weaver 31).

The novelist, poet, ethnographer, and expert on Afro-Cuban culture Miguel Barnet examines the poem as the poet identification with Yemayá is so strong; even Morejón's close friend associates her with the orisha of the sea (Barnet xi). The poet met her mother Yemayá who created the rebirth of a new strong 
woman who resisted oppression. The daughter of Yemayá, Morejón, rebirth was at the time of revolution when the poet participated in the Cuban revolution with Fidel Castro.

Yemayá is Morejón's universal mother, which also can be perceived in Morejón's poem "Mother." The poet fuses both the universal icon mother, Yemayá, and her own birth mother. She says:

My mother had no garden

but rather steep islands

floating beneath the sun,

on their delicate corals (Cook 211).

The poet indirectly connects her birth mother with Yemayá in the first few lines, using images of the sea to invoke her own mother. So, the reader imagines Yemayá's coral garden bathing Morejón's mother at the limestone-floored orphanage.

What a time that was when she ran, barefoot, on the limestone of the orphanages and she did not know how to laugh and she could not even gaze at the horizon

My mother had the song and the handkerchief

to cradle my heart's faith

to lift her head of a queen, ignored,

and to leave us her hands, like precious stones, (Cook 211).

She continues the poem with verses from her own personal memories of her birth mother. Although she suffered in the orphanages, but she was a happy mother with faith and vision to support her daughter (Cook 249).

Another reference to both mothers is in the poem "Coffee" "Mama brings coffee from remote seas" (Cook 249). The coffee mama serves at home is at the same time being transported by mother Yemayá across as ships' cargo (González 957-8).

In addition, in the poem "By the Gulf", again the poet connects the gulf with the God Yemayá for the sake of protection and cultural resistance.

Runaway slave

at night we are in the blue

Waters and you are finding new islands

New being (Cook 287).

González argues that, the poet reaffirms the past of her African ancestors in which the poem strongly links the living dead with reality. Morejón begins 
the poem with an epigraph from Nicolás Guillén "dramatic galley slaves, dramatic galley slaves" (Cook 287). The repetition of these words refers to the slave trade and continuous wave after wave on the sea. The poem refers to the Gulf of Guinea, along which is the so called "Slave Coast", known by its role in human trafficking and refers to Yemayá (González 963). The mother Yemayá protects the runaway while bringing him to a new coast, a new beginning by the sea.

West states that all the above poems signify that Morejón's poems bring together African mythology and Cuban images to fashion uniquely African Cuban identity. She brought together a true example of Cuban transculturation. Orishas are symbols of destiny, chance, and justice, merge with the power of faith, miracles, racial harmony, social justice, fate, faith, and utopian fulfilment through faith and revolution come together in the vigorous images of powerful poems (West 195-6).

In the poem "In Praise of Nieves Fresneda", González points out that, Morejón signs the poem with "Nieves" to signify her uniqueness as a human being. Nieves Fresneda is a Cuban folk dancer, ballerina and the principal dancer of the National Folkloric. The poet strongly connects Fresneda with Orisha Yemayá. Morejón also relates her image to the Orisha Yemayá, she describes her in the first verse "like a flying fish: Nieves Fresneda" (Cook 164). This verse does not only describe Fresneda's dancing ability but connects her with the Orisha Yemayá as the mother whose children are the fish (West 197). Fresneda is the daughter of Yemayá who dances to her orisha worldwide. Fresneda style has become the classic dance for Yemayá in Havana (González 958).

Ocean waves, galley slaves,

Blue petals of seaweed

Cover her days and hours, are reborn at her feet.

A murmur of Benin

Carried her to the depths of this land (Cook 171).

The poet immediately draws a significant image of slaves and Cuba in one verse. Alan West notes, Morejón connects sea waves with galley slaves with whisper of Benin, which brings her with the depth of Cuba. Morejón connects the beauty of Yemayá with the deep pain of historical reality of slavery (West 197). The poet also connects Fresneda with two colours blue and white which are Yemayá's colours. The moon and its silvery light are also elements of 
Aesthetic Resistance Theory: The Use of Mythology in Selected Poems by Nancy Morejón

Yemayá (González 958). Morejón is enhancing the African Cuban identity by integrating prominent aspects from the African religion and culture to Cuban culture. Finally, we have a well-designed fabric of African Cuban identity.

Morejón implements mythology as an instrument of resistance which places her poems as pattern of aesthetic resistance poetry. The poet resists oppression and calls for collective black culture identity through assimilation with Cuban identity. The poems are mirror of the real life and culture of the Afro Cubans. In addition, the discussed poems are in consistent with Albert Camus in The Rebel that resistance is pre-condition for civilization and the good literary work maintains a balance between the real and the imaginary (Camus 274). Mythology is a strong nonviolent resistance tool to resist oppression and recover one's identity and dignity.

Morejón's poems played significant role in the Cuban society as Afro Cuban now accepts Afro Cuban identity through cultural integration. Johnica Hawkins states in her article entitled "Discovering the African Heartbeat in Cuba" the African history, traditions, and customs are essential to the Cuban identity to the extent that you cannot separate between them. This brings to the light a fact that blackness is part of the Cuban identity, for instance the African rhythm and drums are now part of the Cuban music. The house of popular religions in Santiago is full of images of Jesus Christ were put side by side with machetes and stuffed reptiles used in Santerían ceremonies. Actually, most of Cubans now follow some sort of Santerían practices. The Cuban saint Virgen de la Caridad, a Black Madonna, closely resembles the African Orisha Ochún with her deep skin tone and bright yellow dress that many Cubans believe them to be one and the same. Most of the Cubans, because of the economic crisis, depend on medicinal recipes passed down by Africans (Hawkins).

\section{Conclusion}

In conclusion, resistance literature creates space for the marginalized to bring ethical and political transformation in the oppressive structure. Morejón suffered from oppression as an African minority, so she decided to resist through her poems. The poet represents the voice of the marginalized African Caribbean and creates space through her resistance poetry. She believes in the power of her poems. The aesthetic resistance of Morejón works lies in its innovation to form opinion as she calls all African in the Caribbean to integrate with the Cuban culture to form new rich African Caribbean culture. 
As long as Theodor and Cudjoe define the aesthetic of the work of art by its function to society, forming opinion and its relation to real life and resistance literature discusses the repressive ideologies and demonstrates the power of the powerless. The poet is a common person but reconfigures reality and fights oppression through her poems. Morejón attains her goal through transculturation by implementing mythology to give voice to African minorities and affirm their significance to resist marginalization and call for collective culture identity. The above discussed poems significantly shed light on how African Cubans cannot be separated from the Cuban culture and believe in Orishas as the source of power to resist oppression. Therefore, Morejón's discussed poems are aesthetic poetry of resistance.

\section{Notes}

' Nicolás Cristóbal Guillén Batista, (10 July 1902 - 16 July 1989), is a Cuban poet of social protest and a leader of the Afro-Cuban movement in the late 1920s and '30s.

ii Selwyn R. Cudjoe is Professor of Africana Studies, Margaret E. Deffenbaugh and LeRoy T. Carlson Professor in Comparative Literature, and, from 1995 to 1999, was the fourth Marion Butler McLean Chair in the History of Ideas at Wellesley College.

iii In the native religion of Yoruba people Orisha are spirits sent by higher divinities for the guidance of all creation and of humanity in particular, on how to live and be successful on Earth. Most Orishas are said to have previously existed in the spirit world, and then become embodied as human beings on Earth.

iv Yoruba people are an African ethnic group. Most Yoruba people speak the Yoruba language. The Yoruba diaspora consists of two main groupings; one of them includes relatively recent migrants, the majority of which moved to the United Kingdom and the United States after major economic and political changes in the 1960s to 1980 s.

iv Yemayá is the major Orisha of water. She is the women protector, a deity of creation, water, motherhood, rivers, lakes, streams, wells, pregnant women, fishermen, shipwreck survivors. 


\section{Bibliography}

Abudu, Gabriel A. "An Interview". Singular Like A Bird: The Art of Nancy Morejón, edited by Miriam Decosta-Willis, Howard U, 1999, pp. 37-42. Appelbaum, Stanley, editor. Introduction to French Poetry: A Dual-Language Book. Dover Publications, 1969.

Apostel, Leo. African Philosophy Myth or Reality? E. Story- Scientia, 1981. Arroyo, Jossianna. "Transculturation, Syncretism, and Hybridity". Critical Terms in Caribbean And Latin American Thought: Historical and Institutional Trajectories, edited by Yolanda Mart í nez-San Miguel, Ben. Sifuentes-J á uregui, and Marisa Belausteguigoitia Algrave. Macmillan, 2006.

Arinto, Patricia. "Women and the Revolution the Poetry of Resistance of Latin American Women writers". The Review of Women's Studies, vol.2, no.2, 1992, pp. 59-71.

Bande, Usha. Writing Resistance: A Comparative Study of the Selected Novels by Women Writers. Indian Institute of Advanced Study, 2008.

Barnet, Miguel. "The Poetry of Nancy Morejón". Kathleen Weaver, editor and translator, Where the Island Sleeps like A Wing by Nancy Morejón. The Black Scholar P, 1985, pp. ix-xi.

Baugh, Edward. "Yoruba from Cuba: Selected Poems by Nicolas Guillen", translated by Salvador Ortiz-Carboneres. peepaltreepress.com, 25 Oct.2014. wWw.peepaltreepress.com/books/yoruba-cuba-selected-poems-nicolasguillen.

Bowser, Jeriah. "Elements of Resistance: Violence, Nonviolence, and the State". The Anarchist Library, 25 Oct.2014.

www.theanarchistlibrary.org/library/jeriah-bowser-elements-of-resistanceviolence-nonviolence-and-the-state.

Brown, Lesley, editor. The New Shorter Oxford English Dictionary on Historical Principles. vol.2, Oxford U, 1993.

Camus, Albert. The Rebel: An Essay on Man in Revolt. Translated by Anthony Bower, Vintage P, 1991.

Certeau, Michel de. The Practice of Everyday Life. Translated by Steven F. Rendail, U of California, 1984.

Connor, Steven. "What if there were no such thing as the aesthetic?". Steven Connor, 9 Nov. 2016. 
www.stevenconnor.com/doingwithoutart.html.

Cook, JuanamarÍa Cordones, editor. Looking Within. Mirar Adentro: selected poems/ poemas escogidos, (1954-2000), Wayne State U,2003.

Cudjoe, Selwyn. Resistance and Caribbean Literature. Ohio U, 1980.

Foran, John, et. al. editors. The Future of Revolutions: Rethinking Radical Change in the Age of Globalization. Zed Books, 2003.

González, Patricia E. "Yoruba Vestiges in Nancy Morejón's Poetry". Callaloo, vol.28, no.4, 2005, pp. 952-966.

Grafe, Adrian, Jessica Stephens editors. Lines of Resistance: Essays on British Poetry from Thomas Hardy to Linton Kwesi Johnson, McFarland, 2012.

González, Patricia E. "Yoruba Vestiges in Nancy Morejón's Poetry”. Callaloo, vol.28, no.4, 2005, pp. 952-966.

Hardt, Michael, and Antonio Negri. Multitude: War and Democracy in the Age of Empire. Penguin, 2004.

Harlow, Barbara. Resistance Literature. Methuen, 1987.

Hawkins, Reed. "Discovering the African Heartbeat in Cuba". Essence, 2 Agu.2016.

https://www.essence.com/authors/johnica-reed-hawkins/

Hohendahl, Peter Uwe. The Fleeting Promise of Art: Adorno's Aesthetic Theory Revisited. Cornell, 2013.

Hoy, David Couzens. Critical Resistance: from Poststructuralism to PostCritique. The MIT, 2004.

Hsiao, Andrew, and Audrea Lim, Editors. The Verso Book of Dissent: From Spartacus to the Shoe -Thrower of Baghdad. Verso, 2010.

Jaja, Jones M. "Myths in African concept of reality". Academic Journals, vol.6, no.2, 2014, pp. 9-14.

Kristeva, Julia, Desire in Language: A Semiotic Approach to Literature and Art. Edited by Leon S. Roudiez, Columbia, 1980.

Khouri, Elias. "The World of meanings in Palestinian Poetry". The lost Memory. Translated by Barbara Harlow, Beirut: Institute for Arab Research, 1982, 245.

Landry, Jim. Orishas: African Gods of Worship. Truth Book, 2016.

Lenardon, Robert J. and Mark P. O. Morford Eds. Classical Mythology. New York: Oxford U, 1999.

Lofton, Ramona (Sapphire). "Dialogue with Nancy Morejón". Translated by Jason Weiss, BOMB Magazine, vol.78, Winter, 1 Jan 2002. 
www.bombmagazine.org/articles/nancy-morej\%C3\%B3n.

Sibley, Frank. "Aesthetic Concepts". Philosophical Review, vol.68, 1959, pp. 421-450.

Slater, Hartley. "Internet Encyclopedia of Philosophy". University of Western Australia, Internet Encyclopaedia of Philosophy and its Authors, 25 Oct.2014. www.iep.utm.edu/aestheti.

Seudatsingh, Anisa. "Responses of the Caribbean People to Oppression and Genocide". SlideShares, 10 July 2014.

www.slideshare.net/Veeshalla100/responses-of-the-caribbean-people-tooppression-and-1.

Theodor, Adorno. Aesthetic Theory. Continuum,1997.

Weaver, Kathyleen, editor and translator, Where the Island Sleeps like A Wing. The Black Scholar, 1997.

Weiss, Gail, Refiguring the Ordinary. Indiana U, 2008.

West, Alan. "Nancy Morejón: Transculturation, Translation and the Poetics of the Caribbean". Callaloo, vol.28, no.4, Fall, 2005, pp. 967-976. 


\section{نظريه المقاومة الجمالية: استخذام الميثولوجي في قصائد مختاره للشاعرة نانسى موريخون}

مستخلص

يعتقد كتّاب المقاومة أن نضالهم غير العنيف من خلال الاعمال الأدبية ذو تأثثر هام وملهم في المقاومة الثقافية.

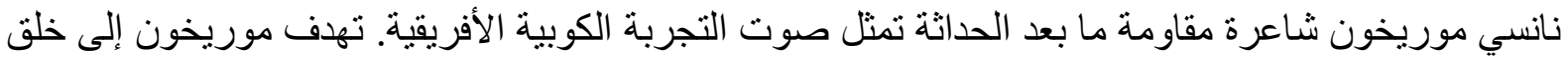

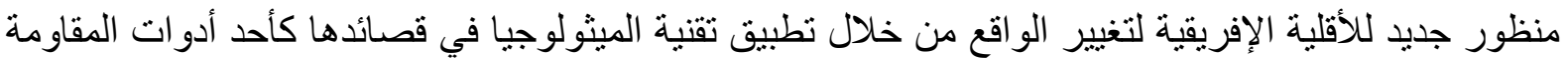

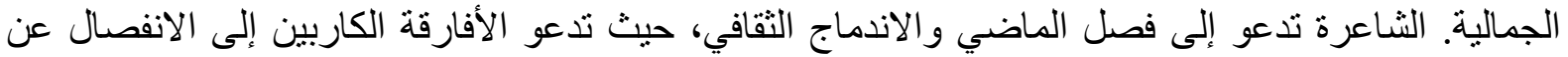
ماضيهم واعتبار منطقة البحر الكاريبي وطنهم الجديد.

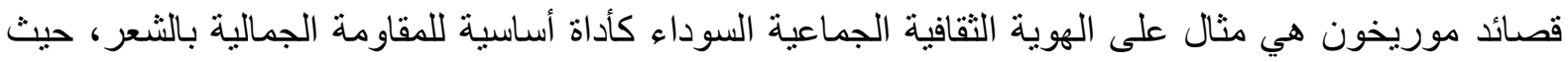

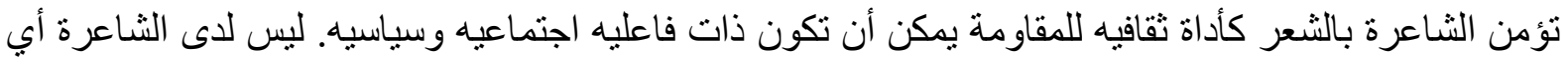

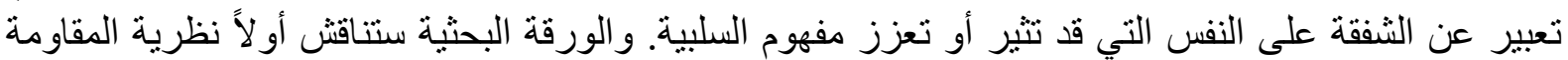

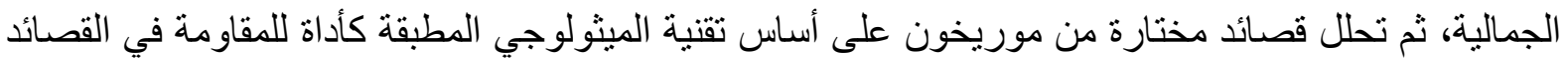

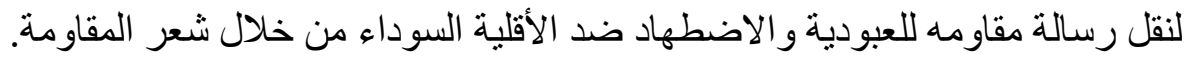

الكلمات الدالة: المقاومة الجمالية ـالثعر ـنظريه المقاومة_الجماليات_شعر المقاومة_المقاومة اللاعنفيه_الهويةـ الميثولوجيا-الميثولوجي 